\title{
Factors influencing Women Employees in Hospitality industry: A Study with reference to Lucknow
}

\author{
Effulgence \\ Vol. 15 No. 2 \\ July-December, 2017 \\ Rukmini Devi Institute of Advanced Studies \\ E-mail : effulgence@rdias.ac.in, Website : www.rdias.ac.in \\ http://effulgence.rdias.ac.in/user/default.aspx \\ https://dx.doi.org/10.33601/effulgence.rdias/v15/i2/2017/64-76
}

\section{Dr. Tripti Barthwal ${ }^{1}$ \\ Dr. Akanksha Srivastava ${ }^{2}$}

\begin{abstract}
The hospitality industry is one of the fastest growing industries in the world. The core of the hospitality industry lies in promptness in service, patience, courtesy, and adaptability towards customers - all qualities which females are generally naturally endowed with. Women are different from men in more than one aspect. Hence, the factors which influence working men may not apply in the same degree to working women. Focusing specifically on women, this study surveyed 50 women executives in the hospitality industry to find out the factors influencing women in this industry. The study first conducted a review of literature to bring out the important factors $\mathcal{E}$ then used factor analysis to discover the key factors influencing the work of women in hospitality. Further, differences in the attitudes of working women on the basis of their age \& marital status were also analyzed through cross tabulations.
\end{abstract}

Keywords: Women, hospitality industry, gender equality, work life balance, career opportunities.

\section{INTRODUCTION}

$\mathrm{H}$ ospitality implies having a good time and undertaking activities to satisfy the customer \& make him feel comfortable. The hospitality and tourism sector is one of the fastest growing service sectors in the world and in Asia this growth is unprecedented. Although the hotel industry has updated \& modernized itself in keeping with the changing trends around the globe, the basic format services in hotels remains more or unchanged in relation with the last century. They are dependent on the critical human elements of service and what
Korczynski (2002) calls "customer sovereignty" to ensure a successful and profitable operation. Their success depends more on their human capital than machineries. Within the human element, it is impossible to imagine a hospitality experience without the charm, courtesy \& grace of women employees.

"The hospitality industry has been traditionally male dominated partly because of the culture and nature of the industry, where job opportunities are more versatile and require senior executives to be flexible with relocation options," said Rainy Chan, general

1. Director (Lal Bahadur Shastri Institute of Management \& Development Studies, Lucknow), Drtbarthwal@gmail.com

2. Associate Prof. (Lal Bahadur Shastri Institute of Management \& Development Studies, Lucknow), akanksha.sincere@gmail.com 
manager of the Peninsula Hong Kong. "For female hoteliers, they often face the dilemma of having to make a choice between family and career, and most of the time, the former always wins the power struggle."

In his working paper for ILO, titled "International perspectives on women and work in hotels", published in 2013 Prof. Baum writes "Hotels, catering and tourism (HCT) is a large and fastgrowing service sector, with an average female participation of 55.5 per cent at global level and up to 70 per cent at regional level. They are employed in a wide variety of roles, including as cleaners and kitchen staff, front-line customer service workers and senior management.

In terms of women and type of hotels, according to Timo and Davidson (2005), the jobs in 4-and 5-star international hotel chains are shared almost equally between female and male counterparts. However, things differ when it comes to managerial positions, which are still dominated by men. Schwartz (1989) emphasizes on the role of women in management as a competitive advantage by stating that it is important for businesses to recognize that female managers are part of a talent pool that is essential to be retained and developed.

\section{OBJECTIVES OF THE STUDY}

The purpose of this study was to identify and examine important factors considered to be susceptible to influence the work domain of female employees in the hospitality industry in Lucknow. This study has the following objectives:

- To study the major factors affecting the work of women in hospitality industry in Lucknow.

- To analyse which of these factors exercise the greatest influence.

- To ascertain the difference in opinions amongst women employees on the basis of marital status.

- To find out the difference in opinions amongst women employees on the basis of their age.

\section{LITERATURE REVIEW}

According to Professor Tom Baum (March 2015), the tourism and hospitality sector has become an economic and social phenomenon, demonstrating above average growth for the fifth consecutive year since the 2009 economic crisis and being set to create 70 million new jobs over the next 10 years.

Males \& females possess different personality attributes \& their working style is also different. Maxwell (1997) has found that, compared to that of their male counterparts, the approach used by female senior managers in their staff management styles such as 'good communication, flexibility and adaptability, and teamwork' have aided them in attaining this rank and provided good outcomes for the organisation. Employees perceived that female managers were more innovative, better able to prioritize and synchronize activities, more readily engaged in mentoring (Vilkinas and Cartn, 1997). Some such as Loscocco (1989) show that women value extrinsic job characteristics more than men do. However, there are other researches that show the opposite (Neil \& Snizek, 1987).

The environment of the hospitality industry, its demands \& customer expectations all are important factors in deciding the role played by different genders. Contributing to a culture that accentuates gender differences is the fact that hospitality employees are often hired, at least in part, because of their physical attractiveness. It becomes clear that women in hospitality experience additional challenges as a result of the nature and characteristics of the industry in which they work (Brownell \& Walsh, 2008).

Besides gender stereotypes, women also have to deal with work life balance issues almost on a daily basis more often than men. Added to this they work in an industry where there is a highly variable demand cycle which imposes unsocial working hours on employees and can make shift patterns unpredictable, which are difficult to reconcile with 
family and care responsibilities. In hotels, the long working day is seen as intrinsic to working practices (Brownell, 1993; Hicks, 1990; Knutson \& Schmidgall, 1999). Seasonal work can demand very high levels of time commitment during some parts of the year, while offering little or no work during the off-season (Baum \& Lundtrop, 2010). It becomes a negative factor for women with young children, as in the majority of cases; women remain the primary caregiver with the added responsibility of household organisation (Lopez - Claros \& Zahidi, 2005).

The implication is clear, points out Brownell \& Walsh (2008) that one primary responsibility is often compromised for the sake of the other. This leads to stress, disappointment \& exhaustion amongst most women. To meet these challenges, some women try to find supportive help at home; others opt for a reduced work schedule and take themselves out of the running for jobs with greater responsibilities and heavier workloads (McGrath, 1999; Higgins et al., 2000).

Kara, Uysal \& Magnini (2012) found that the level of job satisfaction is determined by four factors: "management conditions", "personal fulfillment", "using ability in the job", and "job conditions". The study results show that significant gender differences exist with regard to the "using ability in the job" dimension of job satisfaction. Maxham (2003) found that job satisfaction positively correlates with customer satisfaction. He argues that employees who are satisfied in their job will provide better service to customers and customer satisfaction will increase. Studies have shown that hospitality and tourism employees most likely to leave the industry because of low job satisfaction, poor working conditions and the absence of motivating factors (Kusluvan \& Kusluvan, 2000). Job satisfaction in the industry is thought to be influenced by a number of factors including long hours, night and weekend schedules, stress, demanding supervisors and duties, lack of personal time and quality of life, routine, and little opportunity for advancement and growth (Pavesic \& Brymer, 1990).
Women 1st (2010) found that there were 5 main barriers preventing women's advancement into management and senior roles. These included:

1. Difficulty of combing work at senior level with caring responsibilities

2. Dominant masculine organisational culture

3. Preconceptions and gender bias

4. Lack of networking and exclusion from informal networks of communication

5. Lack of visible women in senior positions

\section{Research gap and contribution of the study}

On the basis of above Review of Literature following points can be concluded:

- It is found that work has done for improving communication between genders in the hospitality workplace.

- It is found that "glass-ceiling" prevent women from reaching top or top executive positions.

- It is found that low female labour participation rates and high male immigrant labour rates contribute to gender imbalance in the hotel workforce.

- It is found that the Indian corporate woman as an endowment to corporate India.

- It is found that work has done to examine WorkLife Balance issues, its extensive impact and identities factors that could help create a better Work-Life Balance in India.

- It is found that women are competing at par with their male counterparts and organizations are also recognizing their talent, irrespective of the gender. Women have made their presence felt in every area. Moreover, they are frontrunner for change and are emerging as leaders in their respective fields.

- It is found that there has been significant growth in the Indian tourism industry during the last few years, particularly after financial year 01-02, there are growing apprehensions regarding the sustainability of tourism as a means of development. This is primarily because of the adverse effect on the environment. 
- It is found that the performance of the working women as an impact of emotional intelligence was segregated into five major groups. The groups are impact in work place, impact of work pressure in family, impact of family pressure in work, gender dynamic and satisfaction level.

- It is found that hotel industry belongs to that group of industries classically segregated by gender. Typically large numbers of women are employed, particularly on the non-managerial side of the organization where the work is semior unskilled, low paid, and classically segregated by gender. Women occupy the low-status roles such as chambermaids, and men occupy the more prestigious roles such as managers and chefs.

In this study researcher would like to explore about satisfaction level of women employees and their security and glass ceiling issues in hospitality industry in Lucknow.

\section{METHODOLOGY \& DATA ANALYSIS}

The study is based on Exploratory Research Design. On the basis of the review of various researches conducted on women on hospitality industry, the researchers first inferred 10 main factors which according to them influenced women working in hospitality industry the most.
1. Commitment to the organization

2. Interest in job profile

3. Managing the peculiar demands of customers

4. Relationship with seniors

5. Punctuality requirements for the job

6. More satisfied if worked elsewhere

7. Capability of men \& women is equal at senior positions

8. Equal career opportunity for men and women

9. Pay inequalities between men and women at same position.

10. Comfortable with extra working hours in special conditions (like festive season etc.)

Then a questionnaire containing 10 statements based on these factors was prepared and respondents were asked to rate these factors on a five point Likert scale on whether they strongly agree, agree, neither agree nor disagree, disagree and strongly disagree with them. Collection of data was done by qualitative methodology on the basis of Non-Probability (Convenience) Sampling.

The study was conducted in Lucknow. Lucknow has a culture of royal hospitality and it has a wide variety/categorization of hospitality industry. The researchers have chosen 5 categories for the collection of data on the basis of significance and the permission of the concerned authorities for their study. The five categories \& the chosen units have been shown in Table 1. The questionnaire was administered to 50 respondents.

Table 1: The Sampling Frame

\begin{tabular}{|l|l|l|l|l|l|}
\hline $\begin{array}{l}\text { Categories } \\
\text { S. No. }\end{array}$ & \multicolumn{1}{|c|}{ Hotels } & Private Clubs & \multicolumn{1}{|c|}{ Resorts } & Lounges & \multicolumn{1}{|c|}{$\begin{array}{l}\text { National } \\
\text { Food Chains }\end{array}$} \\
\hline 1. & $\begin{array}{l}\text { Gemini } \\
\text { Continental }\end{array}$ & Genesis Club & $\begin{array}{l}\text { Dream World Fun } \\
\text { Resort }\end{array}$ & Nashwa & Pizza Hut \\
\hline 2. & $\begin{array}{l}\text { Dayal } \\
\text { Paradise }\end{array}$ & Scorpio Club & Charans Resort & $\begin{array}{l}\text { Zero } \\
\text { Degree }\end{array}$ & Mc' Donald \\
\hline 3. & Comfort Inn & $\begin{array}{l}\text { Dayal Royal } \\
\text { Club }\end{array}$ & Buddha Resort & Blue & Dominos \\
\hline 4. & Madhurima & $\begin{array}{l}\text { Chancellor } \\
\text { Club }\end{array}$ & Anandi Resort & Mint & KFC \\
\hline 5. & Tulip Inn & M.B. Club & Jalsa Resort & Aura & CCD \\
\hline
\end{tabular}


Factor Analysis and KMO and Barlett's Test were conducted and to find out the results from these methods SPSS software was used.

Then factor analysis was applied so that the appropriateness of data can be through the KaiserMeyer-Ohlin (KMO) measure of sample adequacy and Barlett's Test of Sphericity which measure the inter correlation of the data. KMO measure of sample adequacy yields value of 0.541 , which is above the acceptable value of 0.500, and Barlett's Test of Sphericity indicates that the correlations between variables are statistically significant (Table 2). The appropriateness of application of factor analysis is, therefore, justified. Extraction Method was Principle Component Analysis and Rotation Method was Varimax. On examination of the Rotated Factor matrix, the following were observed:

Table 2: Descriptive Statistics

\begin{tabular}{|l|c|c|c|}
\hline \multicolumn{1}{|c|}{ Statements } & Mean & $\begin{array}{c}\text { Std. } \\
\text { Deviation }\end{array}$ & Analysis N \\
\hline Interest in job profile & 4.77 & .470 & 50 \\
\hline Relationship with seniors & 4.29 & .457 & 50 \\
\hline Punctual on job & 4.33 & .854 & 50 \\
\hline More satisfied if worked elsewhere & 2.83 & 1.012 & 50 \\
\hline Commitment to the organization & 4.58 & .496 & 50 \\
\hline Manage the peculiar demands of customers & 4.23 & .827 & 50 \\
\hline Women are as capable as men at senior positions & 4.54 & .501 & 50 \\
\hline Equal career opportunity for men and women & 4.04 & .893 & 50 \\
\hline Pay inequalities between men and women at same post & 3.08 & .867 & 50 \\
\hline $\begin{array}{l}\text { Comfortable with extra working hours in special conditions (like festive } \\
\text { season etc.) }\end{array}$ & 4.06 & .519 & 50 \\
\hline
\end{tabular}

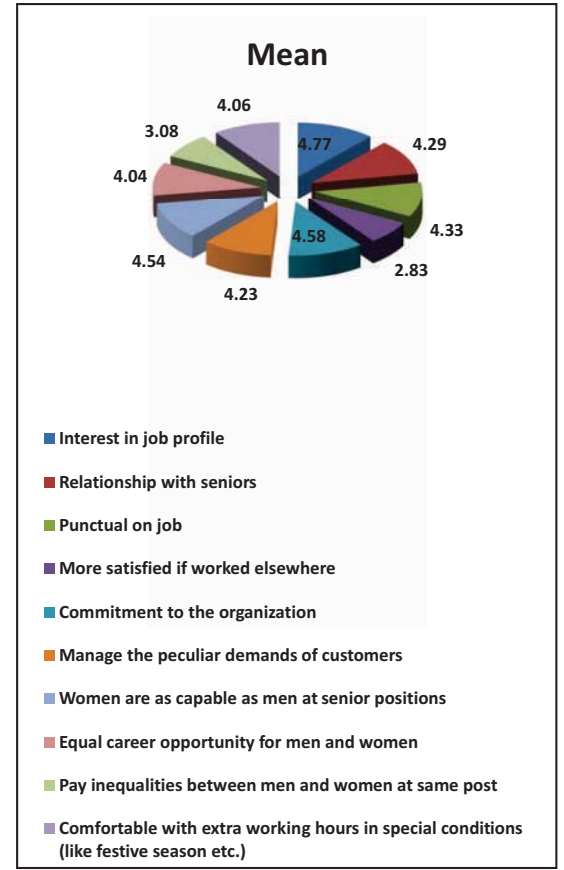

68 


\begin{tabular}{|l|l|r|}
\hline \multicolumn{3}{|c|}{ Table 3: KMO and Bartlett's Test } \\
\hline $\begin{array}{l}\text { Kaiser-Meyer-Olkin } \\
\text { Adequacy. }\end{array}$
\end{tabular}

Interpretation: The next item from the output is the Kaiser-Meyer-Olkin (KMO) and Bartlett's test. The KMO measures the sampling adequacy which should be greater than 0.5 for a satisfactory factor analysis to proceed. From the analysis, the KMO measure is 0.541. From the Table 3, the Bartlett's test of sphericity is significant.

\section{Table 4: Communalities}

\begin{tabular}{|l|l|l|}
\hline \multicolumn{1}{|c|}{ Statements } & Initial & Extraction \\
\hline Interest in job profile & 1.000 & .713 \\
\hline Relationship with seniors & 1.000 & .727 \\
\hline Punctual on job & 1.000 & .780 \\
\hline More satisfied if worked elsewhere & 1.000 & .678 \\
\hline Commitment to the organization & 1.000 & .708 \\
\hline Manage the peculiar demands of customers & 1.000 & .715 \\
\hline Women are as capable as men at senior positions & 1.000 & .709 \\
\hline Equal career opportunity for men and women & 1.000 & .761 \\
\hline Pay inequalities between men and women at same post & 1.000 & .743 \\
\hline $\begin{array}{l}\text { Comfortable with extra working hours in special conditions (like festive } \\
\text { season etc.) }\end{array}$ & 1.000 & .656 \\
\hline Extraction Method: Principal Component Analysis. & & \\
\hline
\end{tabular}

Interpretation: The next item from the output is a table of communalities (Table 4) which shows how much of the variance in the variables has been accounted for by the extracted factors. From the analysis over $78 \%$ of the variance in punctuality on job is accounted for while $65.6 \%$ of the variance in comfortable with extra working hours in special conditions (like festive season etc.) is accounted for. 


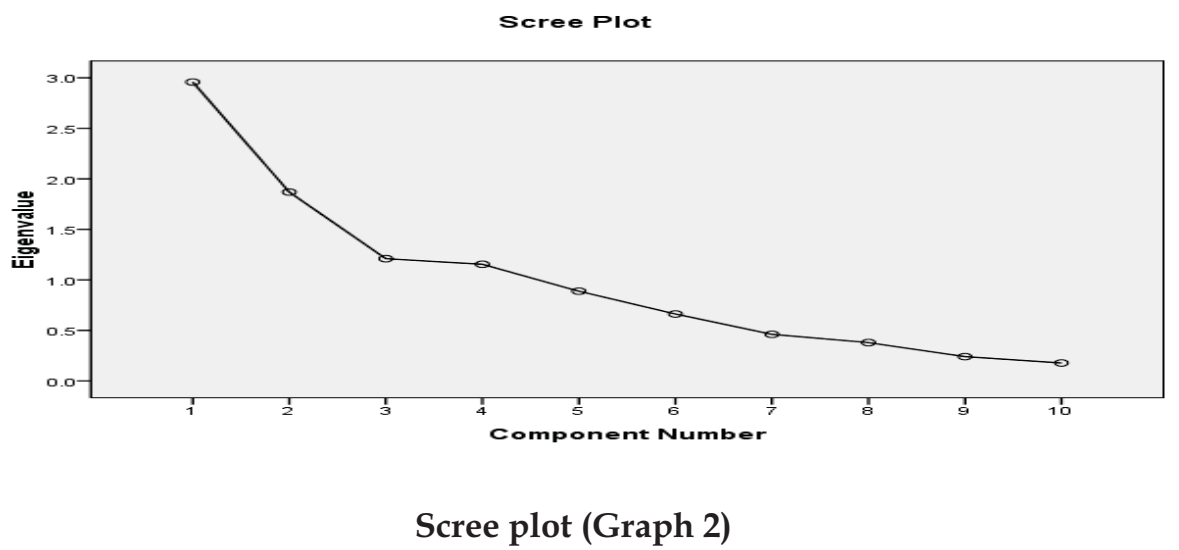

Interpretation: The scree plot is a graph of the eigenvalues against all the factors. The graph is useful for determining how many factors to retain. The point of interest is where the curve starts to flatten. It can be seen that the curve begins to flatten between factors 4 and 5 . And factor 5 has an eigenvalue of less than 1 , so only four factors have been retained.

Table 5: Component Matrix

\begin{tabular}{|c|c|c|c|c|}
\hline \multirow[b]{2}{*}{ Statements } & \multicolumn{4}{|c|}{ Component } \\
\hline & 1 & 2 & 3 & 4 \\
\hline Pay inequalities between men and Women at same post & $\begin{array}{l}- \\
.856\end{array}$ & & & \\
\hline More satisfied if worked elsewhere & $\begin{array}{l}- \\
.689\end{array}$ & & .369 & \\
\hline Manage the peculiar demands of customers & .650 & & .379 & \\
\hline Commitment to the organization & .532 & $\begin{array}{l}- \\
.516\end{array}$ & .387 & \\
\hline Relationship with seniors & & .777 & & \\
\hline Comfortable with extra working hours in Special conditions (like festive season etc.) & $\begin{array}{l}- \\
.420\end{array}$ & $\begin{array}{l}- \\
.568\end{array}$ & $\begin{array}{l}- \\
.372\end{array}$ & \\
\hline Punctual on job & $\begin{array}{l}- \\
.497\end{array}$ & .559 & .454 & \\
\hline Equal career opportunity for men and women & .449 & .419 & $\begin{array}{l}- \\
.608\end{array}$ & \\
\hline Interest in job profile & .311 & & & .751 \\
\hline Women are as capable as men at senior positions & .544 & & & .635 \\
\hline \multicolumn{5}{|l|}{ Extraction Method: Principal Component Analysis. } \\
\hline a. 4 components extracted. & & & & \\
\hline
\end{tabular}

Interpretation: Table 5 shows the loadings of the ten variables on the four factors extracted. The higher the absolute value of the loading, the more the factor contributes to the variable. The gap on the table represents loadings that are less than 0.5 . 
Table 6: Rotated Component Matrix ${ }^{a}$

\begin{tabular}{|c|c|c|c|c|}
\hline & \multicolumn{4}{|c|}{ Component } \\
\hline & 1 & 2 & 3 & 4 \\
\hline $\begin{array}{l}\text { Manage the peculiar } \\
\text { demands of customers }\end{array}$ & .835 & & & \\
\hline $\begin{array}{l}\text { Commitment to the } \\
\text { organization }\end{array}$ & .824 & & & \\
\hline $\begin{array}{l}\text { Pay inequalities } \\
\text { between men and } \\
\text { women at same post }\end{array}$ & -.635 & .477 & & \\
\hline \multicolumn{5}{|l|}{ Interest in job profile } \\
\hline $\begin{array}{l}\text { More satisfied if } \\
\text { worked elsewhere }\end{array}$ & & .768 & & \\
\hline \multicolumn{5}{|l|}{$\begin{array}{l}\text { Relationship with } \\
\text { seniors }\end{array}$} \\
\hline \multicolumn{5}{|l|}{$\begin{array}{l}\text { Comfortable with extra } \\
\text { working hours in } \\
\text { special conditions (like } \\
\text { festive season etc.) }\end{array}$} \\
\hline $\begin{array}{l}\text { Punctual on job } \\
\text { Equal career } \\
\text { opportunity for men } \\
\text { and women }\end{array}$ & -.420 & .509 & .587 & \\
\hline $\begin{array}{l}\text { Women are as capable } \\
\text { as men at senior } \\
\text { positions }\end{array}$ & & & & .785 \\
\hline \multicolumn{4}{|c|}{$\begin{array}{l}\text { Extraction Method: Principal Component Analysis. } \\
\text { Rotation Method: Varimax with Kaiser Normalization. }\end{array}$} & \\
\hline a. Rotation converged is & iterations. & & & \\
\hline
\end{tabular}

The items cluster into these four groups defined by high loadings.
Interpretation: The idea of rotation is to reduce the number factors on which the variables under investigation have high loadings. Rotation does not actually change anything but makes the interpretation of the analysis easier.

From the Table 6 it is clear that:

- Manage the peculiar demands of customers and commitment to the organization are substantially loaded on Factor (Component) 1

- Interest in job profile and more satisfied if worked elsewhere are substantially loaded on Factor 2

- Relationship with seniors and comfortable with extra working hours in special conditions(like festive season etc.) are substantially loaded on Factor 3; and

- Equal career opportunity for men and women 
and women are as capable as men at senior positions are substantially loaded on Factor 4.

These factors can be used for further analysis. The Factor Analysis resulted in four factors named as under:

1. Women Employees' Contribution to the Organization

2. Satisfaction Level of the Women Employees
3. Working Condition of the Organization

4. Glass Ceiling in the organization.

These four factors were found to have eigen value greater than 1 and hence they are significant. The factor loading of the variables determining satisfaction in each factor are been explained in the Table 6.

Table 7: Factor Loading of Variables

\begin{tabular}{|c|c|c|c|c|}
\hline Factor & Variables & $\begin{array}{l}\text { Factor } \\
\text { Loading }\end{array}$ & $\begin{array}{l}\text { Eigen } \\
\text { Value }\end{array}$ & $\begin{array}{c}\text { Percentage of } \\
\text { Variation } \\
\text { Explained }\end{array}$ \\
\hline $\begin{array}{l}\text { Women } \\
\text { Employees } \\
\text { Contribution } \\
\text { To the } \\
\text { Organization }\end{array}$ & $\begin{array}{l}\text { Manage the peculiar demands of } \\
\text { customers } \\
\text { - Commitment to the organization }\end{array}$ & $\begin{array}{l}.835 \\
.824\end{array}$ & 2.958 & 29.580 \\
\hline $\begin{array}{l}\text { Satisfaction Level } \\
\text { of the Women } \\
\text { Employees }\end{array}$ & $\begin{array}{l}\text { - } \quad \text { Interest in job profile } \\
\text { - } \quad \text { More satisfied if worked } \\
\text { elsewhere }\end{array}$ & $\begin{array}{l}.844 \\
.768\end{array}$ & 1.869 & 18.690 \\
\hline $\begin{array}{l}\text { Working } \\
\text { Condition of the } \\
\text { Organization }\end{array}$ & $\begin{array}{l}\text { - Relationship with seniors } \\
\text { hours in special conditions (like } \\
\text { festive season etc.) }\end{array}$ & $\begin{array}{l}.828 \\
.751\end{array}$ & 1.210 & 12.097 \\
\hline $\begin{array}{l}\text { Glass Ceiling in } \\
\text { the organization }\end{array}$ & $\begin{array}{l}\text { - Equal career opportunity for men } \\
\text { and women } \\
\text { - Women are as capable as men at } \\
\text { senior positions }\end{array}$ & $\begin{array}{l}.831 \\
.785\end{array}$ & 1.154 & 11.545 \\
\hline
\end{tabular}

Interpretation: Table 7 depicts how the 4 factors affect the role of women in hospitality industry specifically in Lucknow city.

Next, the above 8 factors were further analysed on the basis of the marital status and age of respondents through cross tabs. 
Table 8: Respondents' Agreement on the basis of Marital Status

\begin{tabular}{|l|l|c|}
\hline \multicolumn{1}{|c|}{ Statements } & \multicolumn{1}{|c|}{$\begin{array}{c}\text { Marital } \\
\text { Status }\end{array}$} & $\begin{array}{c}\text { Respondents } \\
\text { Agreement }\end{array}$ \\
\hline \multirow{2}{*}{ Interest in job profile } & Married & $100 \%$ \\
\cline { 2 - 3 } & Unmarried & $97.1 \%$ \\
\hline Relationship with seniors & Married & $100 \%$ \\
\cline { 2 - 3 } & Unmarried & $100 \%$ \\
\hline More satisfied if worked elsewhere & Married & $14.3 \%$ \\
\cline { 2 - 3 } & Unmarried & $44.1 \%$ \\
\hline \multirow{2}{*}{ Manage the peculiar demands of customers } & Married & $78.6 \%$ \\
\cline { 2 - 3 } & Unmarried & $91.2 \%$ \\
\hline Comfortable with extra working hours in special & Married & $71.4 \%$ \\
\cline { 2 - 3 } conditions (like festive season etc.) & Unmarried & $97.3 \%$ \\
\hline Commitment to the organization & Married & $100 \%$ \\
\cline { 2 - 3 } & Unmarried & $100 \%$ \\
\hline Women are as capable as men at senior positions & Married & $100 \%$ \\
\cline { 2 - 3 } & Unmarried & $100 \%$ \\
\hline \multirow{2}{*}{ Equal career opportunity for men and women } & Married & $100 \%$ \\
\cline { 2 - 3 } & Unmarried & $82.4 \%$ \\
\hline
\end{tabular}

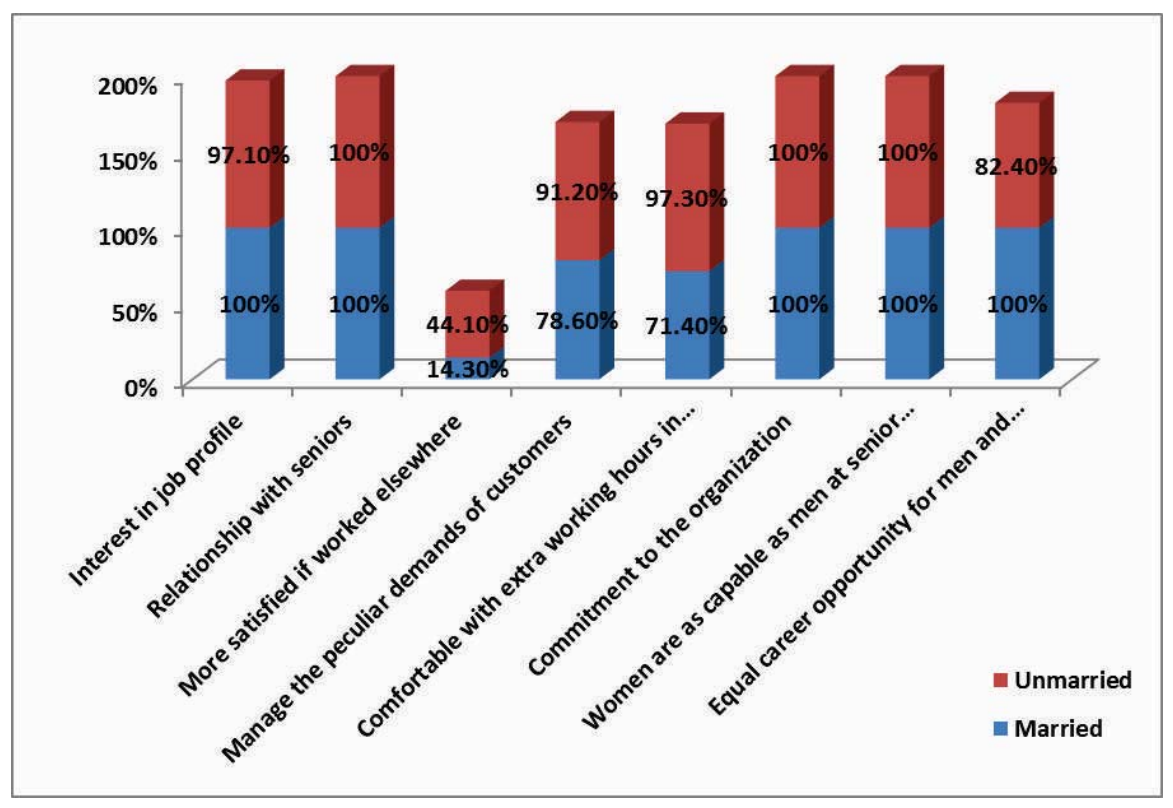

Graph 3 
Interpretation: From the Table 8 \& Graph 3 we can see that married women are more stable employees while unmarried women employees are more mobile. One more point is visible that married women employees are less comfortable with extra working hours because they have to maintain a balance between work \& life.

Table 9: Respondents' Agreement on the basis of Age

\begin{tabular}{|c|c|c|}
\hline Statements & Respondents Age & $\begin{array}{c}\text { Respondents } \\
\text { Agreement }\end{array}$ \\
\hline \multirow[t]{5}{*}{ Interest in job profile } & $20-25$ years & $96 \%$ \\
\hline & $25-30$ years & $100 \%$ \\
\hline & $30-35$ years & $100 \%$ \\
\hline & $35-40$ years & $100 \%$ \\
\hline & Above 40 & $100 \%$ \\
\hline \multirow[t]{5}{*}{ Relationship with seniors } & $20-25$ years & $100 \%$ \\
\hline & $25-30$ years & $100 \%$ \\
\hline & 30-35 years & $100 \%$ \\
\hline & $35-40$ years & $100 \%$ \\
\hline & Above 40 & $100 \%$ \\
\hline \multirow[t]{5}{*}{ More satisfied if worked elsewhere } & $20-25$ years & $48 \%$ \\
\hline & $25-30$ years & $33.3 \%$ \\
\hline & $30-35$ years & $16.7 \%$ \\
\hline & $35-40$ years & $0 \%$ \\
\hline & Above 40 & $0 \%$ \\
\hline \multirow[t]{5}{*}{ Manage the peculiar demands of customers } & $20-25$ years & $88 \%$ \\
\hline & $25-30$ years & $100 \%$ \\
\hline & $30-35$ years & $83.3 \%$ \\
\hline & $35-40$ years & $100 \%$ \\
\hline & Above 40 & $0 \%$ \\
\hline \multirow[t]{5}{*}{ Comfortable with extra working hours in special conditions (like festive season etc.) } & $20-25$ years & $96 \%$ \\
\hline & $25-30$ years & $91.7 \%$ \\
\hline & 30-35 years & $100 \%$ \\
\hline & $35-40$ years & $0 \%$ \\
\hline & Above 40 & $100 \%$ \\
\hline \multirow[t]{5}{*}{ Commitment to the organization } & $20-25$ years & $100 \%$ \\
\hline & $25-30$ years & $100 \%$ \\
\hline & 30-35 years & $100 \%$ \\
\hline & $35-40$ years & $100 \%$ \\
\hline & Above 40 & $100 \%$ \\
\hline \multirow[t]{5}{*}{ Women are as capable as men at senior positions } & $20-25$ years & $100 \%$ \\
\hline & $25-30$ years & $100 \%$ \\
\hline & 30-35 years & $100 \%$ \\
\hline & $35-40$ years & $100 \%$ \\
\hline & Above 40 & $100 \%$ \\
\hline \multirow[t]{5}{*}{ Equal career opportunity for men and women } & $20-25$ years & $76 \%$ \\
\hline & $25-30$ years & $100 \%$ \\
\hline & 30-35 years & $100 \%$ \\
\hline & $35-40$ years & $100 \%$ \\
\hline & Above 40 & $100 \%$ \\
\hline
\end{tabular}




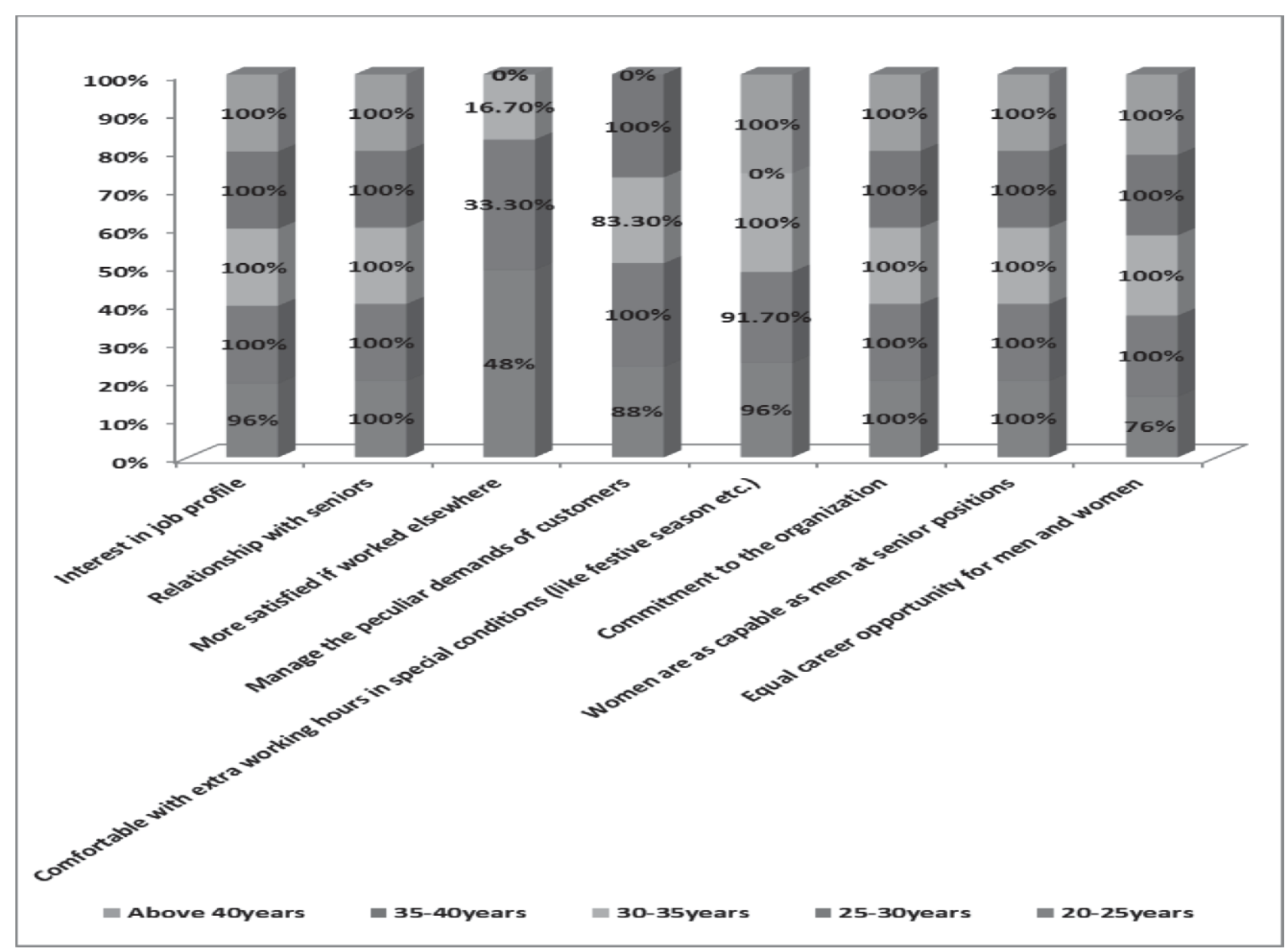

\section{Graph 4}

Interpretation: From Table 9 \& Graph 4 it is clear that with the increase in age loyalty towards organization increases. In initial stage and in later stage women employees are comfortable with extra working hours while in middle stage (between 2530years: it is phase when a female is planning about her marriage \& between 35-40years : it is phase when a female is planning about her kids) they are less comfortable with extra working hours.

\section{CONCLUSION}

On the basis of the data analysis, the following conclusions can be drawn:

- Interest in job profile \& relationship with seniors are most important for the women working in hospitality industry.

- Four factors which affect the working women in hospitality industry the most are:
- Their contribution to the organisation.

- Their level of job satisfaction.

- The working condition of the organization.

- Existence of glass ceiling in the organization.

- Married women are more satisfied with their present organisation in comparison to unmarried ones.

- Relationships with seniors are cordial across all age groups \& marital status.

- Loyalty towards organisation tends to increase with age.

- Women employees between 25-40 years are not very comfortable with long working hours.

\section{REFERENCES}

1) Baum, T. \& Lundtorp S. (2000). Seasonality in Tourism, London, Elsevier.

2) Baum, T. (2015). White Paper Women in Tourism 
\& Hospitality: Unlocking the Potential in the Talent

Pool https://www.diageo.com/Lists/.../Women_in_ Hospitality___Tourism_White_Paper.pd... (accessed on $27^{\text {th }}$ May, 2017)

3) Brownell, J., \& Walsh, K. (2008). Women in hospitality [Electronic version]. Retrieved [May 24, 2017], from Cornell University, SHA School $\begin{array}{lllll}\mathrm{s} & \mathrm{i} & \mathrm{t} & \mathrm{e}\end{array}$ http://scholarship.sha.cornell.edu/articles/835

4) Hicks, L. (1990). Excluded Women: How can this Happen in the Hotel World. The Service Industries Journal, 10(2), 348-363.

5) Higgins, C. Duxbury, L. Johnson, K. L. 'Part time work for women: does it really help balance work 126 and family?' Human Resource Management $39 \quad$ (1) 17-32. (2000). http:/ / dx.doi.org/10.1002/\%28SICI\%291099050X\%28200021\%2939:1\%3C17::AIDHRM3\%3E3. $0 . \mathrm{CO} ; 2-\mathrm{Y}$

6) Kara D., Uysal M., Magnini Vincent P., (2012) "Gender differences on job satisfaction of the five-star hotel employees: The case of the Turkish hotel industry", International Journal of Contemporary Hospitality Management, Vol. 24 Issue: 7, pp.1047-1065, doi: 10.1108/09596111211258919

7) Knutson, B. J., \& Schmidgall, R. S. (1999). Dimensions of the Glass Ceiling in the Hospitality Industry. Cornell Hotel and Restaurant Administration Quarterly, 40(6), 6470.

8) Korczynski, M. (2002). Human Resource Management in Service Work. London: Palgrave

9) Kusluvan, S., \& Kusluvan, Z. (2000). Perceptions and attitudes of undergraduate tourism students towards working in the tourism industry in
Turkey. Tourism Management, 21, 251-269.

10) Loscocco, K. (1989). The interplay of personal and job characteristics in determining work commitment. Social Science Research, 18, 70-79.

11) Lopez - Claros, A., \& Zahidi, S. (2005). Women's Empowerment-Measuring the Global Gender Gap: Harvard Business Review.

12) Maxham, J. A. N., R. (2003). Firms reap what they sow: The effects of shared values and peceived organizational justice on customers' evaluations of complaint handling. Journal of Marketing, 67(1), 46-62.

13) Maxwell, G. A. (1997) "Hotel general management: views from above the glass ceiling." International Journal of Contemporary Hospitality Management 9, (5/6) 230-235. http://dx.doi.org/10.1108/09596119710172624

14) McGrath, C. 'Do females want to be the future?' Hospitality 8. (1999).

15) Neil, C. C., \& Snizek, W. E. (1987). Work values, job characteristics, and gender. Sociological Perspectives, 30, 245-265.

16) Pavesic, D., \& Brymer, R. (1990). Job satisfaction: what's happening to the young managers? The Cornell Hotel and Restaurant Administration Quarterly, 30(4), 90-96.

17) Schwartz, F. (1989). Management Women and the New Facts of Life. Women in Management Review. 4(5), 65-76.

18) Timo, N., \& Davidson, M. (2005) "A survey of employee relations practices and demographics of MNC chain and domestic luxury hotels in Australia." Employee Relations 27, (2) 175-192.

19) Vilkinas, T. and Cartan, G. 1997. How different are the roles displayed by female and male managers?. Women in Management Review, 12(4): 129-135. 